\title{
SKALA PENGUKURAN KUALITAS LAYANAN: SEBUAH KAJIAN LITERATUR
}

\author{
Dewa Nyoman Benni Kusyana ${ }^{1}$ \\ Komang Ary Pratiwi ${ }^{2}$ \\ ${ }^{(1,2)}$ Fakultas Ekonomi Bisnis dan Pariwisata Universitas Hindu Indonesia, \\ Denpasar \\ email : benni.unhi@gmail.com
}

\begin{abstract}
Service quality measurement techniques along with dimensions of service quality have become a major issue in the marketing literature over the past few decades. The increasing importance of quality services, both practitioners and scholars began to focus on service delivery. Measurement of service quality is now seen as an important measurement tool for companies to understand the needs and desires of customers by analyzing customer satisfaction and experience with the services provided. Although until now there has been no agreement on a particular model that should be used to measure service quality, the fact is there are several effective models that can be used by both practitioners and scholars that have been produced by researchers. Until now, researchers believe and agree that service quality is multilevel or multidimensional. This study focuses on various types of service quality models that existed until year of 2000. The methodology used is conducting a review of service quality literature. The limitation of this literature review is that the existing service quality model was developed before 2000 because after 2000 the development of quality services was focused on the quality of electronic services.
\end{abstract}

Keywords: service quality, measurement of service quality, service quality model, customer satisfaction.

\section{PENDAHULUAN}

Dewasa ini, dalam konteks globalisasi, kualitas layanan masih memegang peranan yang sangat penting dan menjadi isu yang tetap menarik untuk dibahas baik oleh praktisi, manajer, dan peneliti karena dianggap sebagai alat yang dapat menciptakan kepuasan pelanggan. Seperti yang diketahui bahwa tujuan utama setiap perusahaan adalah untuk menciptakan keuntungan dan meningkatkan produktivitas. Mendapatkan pelanggan baru dan meningkatkan jumlah pelanggan 
tentunya akan meningkatkan penjualan perusahaan. Cara terbaik yang dapat digunakan untuk mencapai tujuan perusahaan adalah dengan mempertahankan pelanggan yang telah ada daripada harus mencari pelanggan baru yang berarti akan membutuhkan biaya lebih besar (Ghotbabadi et al, 2015).

Meskipun banyak perusahaan percaya bahwa mempertahankan pelanggan lebih baik daripada mendapatkan pelanggan baru, faktanya adalah kualitas baik itu kualitas layanan atau kualitas produk adalah kunci sukses untuk memotivasi pelanggan memiliki niat melakukan pembelian. Kegiatan bisnis pada dasarnya dibagi dalam dua kategori utama yaitu barang dan jasa yang mana kualitas produk dan kualitas layanan akan mempengaruhi kepuasan, loyalitas, dan niat melakukan pembelian (Bowen dan Chen, 2001; Parasuraman et al, 1985). Industri jasa pada umumnya berbeda dengan manufaktur karena memiliki karakteristik seperti tidak berwujud, dikonsumsi langsung, bervariasi, tidak bisa disimpan, dan tidak menyebabkan terjadi pengalihan kepemilikan sehingga menyebabkan sulitnya untuk mengevaluasi jasa. Adanya karakteristik jasa tersebut juga mengakibatkan pengeukuran terhadap faktor-faktor yang terkait dengan jasa akan menjadi lebih sulit dibanding industri manufaktur (Siu dan Cheung, 2001).

Kualitas layanan telah didiskusikan secara luas sejak abad ke dua puluh meskipun model-model kualitas layanan ditemukan dan dikemukakan oleh para peneliti sebelum tahun 2000, sehingga hingga saat ini masih dianggap sebagai isu dan strategi yang relevant untuk membantu perusahaan dalam menciptakan perbedaan dan keunggulan kompetitif pada era globalisasi dan dunia tanpa batas (Ali et al, 2016; Fotaki, 2015). Definisi kualitas layanan yang umum digunakan adalah tingkat di mana suatu pelayanan mampu memenuhi kebetuhan atau harapan pelanggan dan melibatkan perbandingan antara harapan dan kinerja aktual pelayanan yang dirasakan oleh pelanggan (Kumar dan Sikdar, 2014).

Prakash dan Mohanty (2012) mengemukakan bahwa ada beberapa faktor yang menyebabkan meningkatnya kepentingan terhadap kualitas layanan, serta banyak industri, perusahaan, dan individual yang telah mendefinisikan ruang lingkup konsep kualitas layanan dan kerangka kerja yang mendefinisikan bidang tersebut. Pertama, konsep kualitas layanan dikembangkan sebagai suatu respon 
seiring dengan pesatnya pertumbuhan industri jasa yang berakibat pada perubahan perekonomian dunia. Kedua, kualitas layanan disadari sebagai bisnis yang sangat penting dalam industri manufaktur dan teknologi informasi. Ketiga, permintaan akan konsep yang lebih spesifik dalam pemasaran jasa datang dari deregulasi industri dan jasa profesional. Kualitas layanan telah menjadi topik yang sangat menarik perhatian bagi praktisi dan peneliti dewasa ini yang dipicu oleh karya Parasuraman et al pada tahun 1985 (Caruana, 2000). Fokus dari literatur pemasaran telah mengalami perubahan seiring dengan terjadinya perubahan pada sebagian besar pasar dari tahun ke tahun.

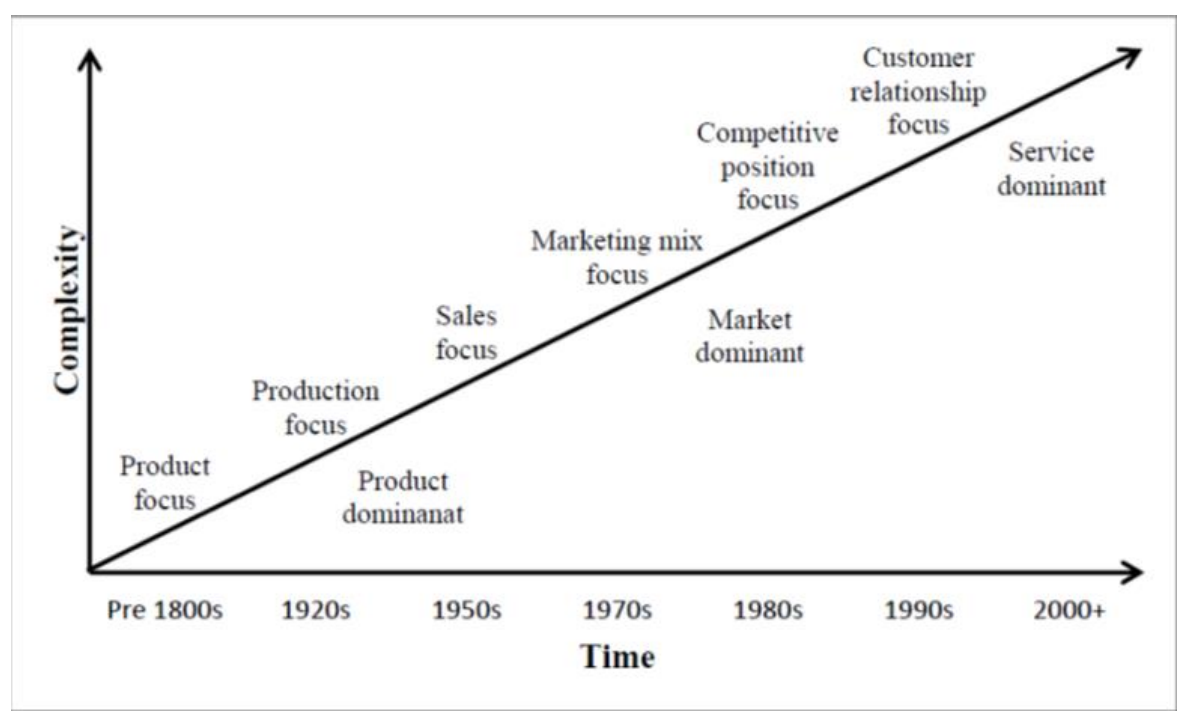

\section{Gambar 1. Perubahan Dominasi Pasar}

Sumber : Harwood dan Garry (2008)

Gambar 1 menunjukkan dominan pasar berubah dan strategi marketing juga mengalami perkembangan dan perubahan mengikuti pasar. Sebelum tahun 1980, pasar dan aktivitas pemasaran didominasi oleh produk, fokus pada produk dan meningkatkan produksi dan penjualan, namun sejak tahun 1980an dominasi berpindah kepada pasar sebagai pengganti produk dan strategi pemasaran mengembangkan teori bauran pemasaran dan berfokus pada posisi bersaing. Sejak tahun 2000an dominasi pasar mengalami pergeraseran kepada pasar jasa. Bisnis jasa mengalami peningkatan dan mendominasi pasar. Seiring dengan terjadi perubahan pada pasar dan kebutuhan pengembangan pemasaran pada industri jasa, cendekiawan dan praktisi merasakan adanya kebutuhan akan pengembangan 
model yang berkelanjutan untuk mengukur kualitas layanan dalam rangka menjaga eksistensi dalam persaingan dan meraih keunggulan kompetitif dalam pasar yang kompetitif. Atas dasar tersebut, peneliti memperkenalkan dan mengembangkan sejumlah model untuk mengukur kualitas layanan, dan meskipun tidak ada kesepakatan hingga saat ini mengnai model apa yang paling tepat untuk digunakan mengukur kualitas layanan, namun kenyataannya berbagai model kualitas layanan tersebut sangat bermanfaat bagi industri jasa. Kajian literatur berikut akan memberikan gambaran mengenai berbagai model dan pengukuran kualitas layanan yang telah dikembangkan.

\section{METODE PENELITIAN}

Penelitian merupakan studi literatur dengan menelaah 51 jurnal terkait kualitas layanan. Hasil dari berbagai telaah literatur ini akan digunakan untuk mengidentifikasi berbagai macam skala pengukuran kualitas layanan yang ada hingga tahun 2000. Jenis data yang digunakan adalah data sekunder dan data kualitatif. Pengumpulan data yaitu menggunakan metode studi pustaka terhadap publikasi jurnal baik berupa scale development maupun hasil penelitian kuantitatif terkait dengan kualitas layanan.

\section{KAJIAN LITERATUR}

\section{Kualitas Layanan}

Pada bagian ini, akan dilakukan pembahasan mengenai berbagai model kualitas layanan yang telah ada, di antaranya ServQual, ServPerf, Retail Service Quality (RSQS) atau kualitas layanan ritel, dan berbagai model kualitas layanan lainnya. Baik ServQual dan dan ServPerf merupakan dua model umum yang digunakan untuk perusahaan berbasis jasa murni, RSQ untuk toko ritel, dan model kualitas layanan lainnya membahas model-model yang dikembangkan lebih spesifik untuk suatu jenis usaha jasa tertentu.

\section{Model ServQual}

Kualitas layanan dapat diukur dengan menggunakan dimensi ServQual, yaitu suatu model yang telah banyak digunakan untuk mengukur kualitas layanan yang pertama kali dikembangkan oleh Parasuaraman et al pada tahun 1988. Model tersebut dianggap sebagai yang paling efisien dalam membantu suatu 
perusahaan untuk meningkatkan kualitas layanan (Kabadayi dan Cirpin, 2016). Model ini dianggap sebagai alat pengukuran kualitas layanan yang paling banyak digunakan untuk mengukur kualitas layanan (Khatibi et al, 2002). Lebih lanjut, Kumar et al (2018) mengungkapkan bahwa ServQUal yang dikemukakan oleh Parasuraman, Zeithaml, dan Berry pada tahun 1988 tersebut memberikan kontribusi yang sangat besar dan menimbulkan banyak ketertarikan. Sebelum merumuskan ServQual pada tahun 1988, Parasuman, Zeithaml, dan Berry telah lebih dulu melakukan penelitian pada tahun 1985 dan merumuskan sepuluh dimensi kualitas layanan sebegai berikut :

1. Reliability (kehandalan), yaitu melibatkan konsistensi dari kinerja dan keterkaitan. Dalam hal ini perusahaan dituntut untuk memberikan jasa dengan benar pada saat yang tepat

2. Responssiveness (ketanggapan), berhubungan dengan kesigapan atau kesediaan dari karyawan untuk menyediakan jasa. Ketanggapan ini melibatkan ketepatan waktu dari jasa.

3. Competence (kemampuan), berarti memiliki pengetahuan dan ketrampilan yang diperlukan untuk melaksanakan jasa.

4. Access (mudah diperoleh), berarti memiliki pendekatan dan mudah melakukan kontak.

5. Corteesy (kehormatan), melibatkan kesopanan, rasa hormat, pertimbangan, dan keakraban dari kontak personil.

6. Communication (komunikasi), berarti memelihara konsumen dengan bahasa yang mudah dimengerti dan mendengarkan konsumen.

7. Credibility (dapat dipercaya), berarti kelayakan, kepercayaan, dan kejujuran.

8. Security (keamanan), berarti bebas dari bahaya, resiko, dan ancaman

9. Understanding/knowing (memahami), yaitu usaha untuk memahami kebutuhan konsumen

10. Tangibles (bukti fisik kasat mata), berarti bukti secara fisik yang meliputi fasilitas fisik, penampilan personil, peralatan, dan perlengkapan yang disediakan. 
Setelah merumuskan sepuluh dimensi kualitas jasa di atas, maka Parasuraman $d k k$. kembali melakukan penelitian pada tahun 1988 yang bertujuan untuk menyempurnakan dimensi kualitas jasa tersebut. Dalam penelitiannya, Parasuraman et al (1988) merumuskan kesepuluh dimensi kualitas jasa tersebut dipertajam menjadi lima dimensi yang dikenal dengan istilah ServQual, yaitu :

1. Reliability (kehandalan), yaitu kemampuan melaksanakan jasa yang dijanjikan secara meyakinkan dan akurat.

2. Responssiveness (ketanggapan), yaitu kesediaan melayani konsumen dan memberikan jasa dengan cepat.

3. Assurance (jaminan), yaitu pengetahuan dan kesopanan serta kemampuan penyedia jasa menyampaikan kepercayaan dan keyakinan.

4. Empathy (empati), yaitu kesediaan memberikan perhatian yang mendalam dan khusus kepada masing-masing konsumen.

5. Tangibles (bukti fisik), yaitu dimensi jasa yang berkaitan dengan penampilan fasilitas fisik, perlengkapan, karyawan, dan bahan komunikasi.

Tabel 1 berikut akan menyajikan informasi perbedaan antara dimensi kualitas layanan yang dikemukakan oleh Parasuraman et al pada tahun 1985 dan 1988.

\section{Tabel 1. Perbandingan Dimensi ServQual tahun 1985 dan 1988}

\begin{tabular}{|c|c|c|}
\hline $\begin{array}{c}\text { Model Awal } \\
(1985) \\
\end{array}$ & $\begin{array}{c}\text { Model setelah direstrukturisasi } \\
\text { (1988) } \\
\end{array}$ & Deskripsi \\
\hline Bukti fisik & Bukti fisik & $\begin{array}{l}\text { Aspek fisik yang disediakan penyedia jasa kepada } \\
\text { pelanggan }\end{array}$ \\
\hline Kehandalan & Kehandalan & Kemampuan untuk memenuhi janji secara akurat \\
\hline Ketanggapan & Ketanggapan & $\begin{array}{l}\text { Kemampuan untuk hadir bagi pelanggan dan } \\
\text { menyediakan layanan dengan cepat, memiliki } \\
\text { kemampuan untuk fleksibel dan beradaptasi terhadap } \\
\text { kebutuhan pengguna jasa }\end{array}$ \\
\hline Kompetensi & & \\
\hline $\begin{array}{l}\text { Kesopanan } \\
\text { Kredibilitas } \\
\text { Keamanan }\end{array}$ & Jaminan & $\begin{array}{l}\text { Kompetensi dan kesopanan kepada pelanggan dan } \\
\text { keamanan yang disediakan }\end{array}$ \\
\hline $\begin{array}{l}\text { Akses } \\
\text { Komunikasi } \\
\text { Pemahaman pengguna }\end{array}$ & Empati & Perhatian individu kepada pelanggan \\
\hline
\end{tabular}


Berdasarkan kelima faktor tesebut, penelitian yang dilakukan mengembangkan 22 (dua puluh dua) atribut skala ServQual dan mencatat adanya wilayah toleransi atau kisaran di mana persepsi tentang dimensi kualitas jasa akan dianggap memuaskan yang diberi batas oleh tingkat minimum yang ingin diterima konsumen dan tingkat yang diyakini konsumen dapat dan harus diserahkan. Tabel 2 berikut akan memberikan detail mengenai dua puluh dua atribut ServQual.

ServQual telah banyak digunakan untuk mengukur kualitas layanan di berbagai jenis usaha seperti perusahaan yang bergerak di bidang perbaikan dan perawatan, provider layanan sambungan telepon jarak jauh, layanan kesehatan (Peprah dan Atara, 2014), industri mobile (Abu-El Samen et al, 2017), eko turisme (Yusof et al, 2014), transportasi (Ojo et al, 2014), pendidikan (Banahene, 2014), dan lainnya. ServQual, dalam beberapa kasus juga telah digunakan untuk mengukur kualitas layanan pada sektor ritel (Kumar et al, 2018) .

\section{Tabel 2. Dimensi ServQual menurut Parasuraman et al (1988)}

\begin{tabular}{|c|c|c|}
\hline Model & Dimensi & Indikator \\
\hline \multirow{22}{*}{ ServQual } & \multirow{4}{*}{ Bukti fisik } & Memiliki peralatan terbaru \\
\hline & & fasilitas fisik terlihat dengan jelas \\
\hline & & karyawan berpakaian dan berpenampilan rapi \\
\hline & & Penampilan fasilitas fisik seuai dengan jasa yang diberikan \\
\hline & \multirow{6}{*}{ Kehandalan } & Ketika perusahaan berjanji melakukan sesuatu, maka akan dilaksanakan \\
\hline & & Ketika pelanggan memiliki masalah, karyawan menunjukkan simpati \\
\hline & & dan meyakinkan \\
\hline & & Memberikan pelayanan yang dapat diandalkan \\
\hline & & Pelayanan dilaksanakan sesuai dengan waktu yang telah dijanjikan \\
\hline & & Mempertahankan catatan secara akurat \\
\hline & \multirow{5}{*}{ Ketanggapan } & Menginformasikan kapan pelayanan akan dilaksanakan \\
\hline & & Memberikan pelayanan dengan cepat \\
\hline & & Karyawan selalu siap untuk membantu pelanggan \\
\hline & & $\begin{array}{l}\text { Karyawan tidak pernah terlalu sibuk untuk untuk menanggapi } \\
\text { permintaan pelanggan dengan cepat }\end{array}$ \\
\hline & & Karyawan dapat dipercaya \\
\hline & \multirow{3}{*}{ Jaminan } & Pelanggan merasa aman untuk bertransaksi dengan penyedia jasa \\
\hline & & Karyawan berperilaku sopan \\
\hline & & $\begin{array}{l}\text { Karyawan mendapatkan dukungan memadai dari perusahaan dalam } \\
\text { melakukan tugasnya }\end{array}$ \\
\hline & \multirow{4}{*}{ Empati } & Perusahaan memberikan perhatian individual \\
\hline & & Karyawan mengetahui kebutuhan pelanggan \\
\hline & & Pelayanan yang diberikan mampu memikat hati pelanggan \\
\hline & & Jam operasional perusahaan sesuai dengan kebutuhan pelanggan \\
\hline
\end{tabular}

Sumber : Parasuraman et al (1988) 


\section{Model ServPerf}

Meskipun model ServQual telah terbukti sebagai suatu alat pengukuran yang baik untuk berbagai industri, banyak hasil penelitian menunjukkan bahwa model tersebut tidak cocok untuk diterapkan pada beberapa bidang industri jasa seperti toko ritel (Dabholkar et al,1996). Beberapa tahun setelah model ServQual dikemukakan perdebatan mengenai model tersebut tidak dapat dihindarkan di antara pada ilmuwan dengan mengatakan bahwa model ServQual tidak secara komprehensif mampu diterapkan di berbagai bidang (Brady dan Cronin, 2001; Dabholkar et al, 1996; Shanin dan Samea, 2010). Pada tahun 1992, Cronin dan Taylor menyarankan model modifikasi dengan mempertimbangkan kinerja aktual sebagai satu-satunya faktor yang perlu diukur dari kualitas layanan. Kedua peneliti tersebut berpendapat bahwa kualitas layanan merupakan sikap konsumen dan kinerja aktual merupakan satu-satunya alat ukur kualitas layanan. Penelitian tersebut juga mempelajari hubungan antara kualitas layanan dengan kepuasan pelanggan dan niat membeli, serta menyarankan suatu model baru untuk kualitas layanan berdasarkan pada ServQual yang kemudian diberi nama ServPerf yang hanya mengukur kinerja aktual dari kualitas layanan, dalam artian tidak mengukur tingkat harapan pelanggan.

Model baru ini tetap menggunakan dimensi yang sama dengan ServQual yaitu bukti fisik, kehandalan, ketanggapan, jaminan, dan empati. Kesimpulan dari penelitian tersebut adalah dimensi ServQual tidak konsisten dan ServPerf adalah alat ukur yang lebih akurat (Cronin dan Taylor, 1994; Seth et al 2005). Atas dasar tersebut, ServPerf lebih dikenal sebagai skala yang hanya mengukur kinerja aktual kualitas layanan, namun memiliki persamaan dengan ServQual yaitu ServPerf tetap mengadopsi lima dimensi beserta 22 indikator dari model ServQual dengan perbedaan utama bahwa ServPerf tidak mengukur harapan pelanggan di mana sikap konsumen sebagai inti dari kualitas layanan sehingga pengukuran berdasarkan kinerja aktual dianggap lebih tepat (Sureshchandar et al, 2001).

\section{Kualitas Layanan Ritel}

Meskipun ServQual telah teruji secara empiris dalam banyak studi melibatkan jasa murni seeprti perbankan, sambungan telepon jarak jauh, 
perusahaan sekuritas, dan layanan kartu kredit, namun tidak pernah berhasil diterapkan dan tervalidasi dalam lingkungan toko ritel (Siu dan Cheung, 2014). Sektor ritel pada dasarnya juga merupakan bagian dari industri jasa yang menawarkan barangkan dan jasa, sehingga manajemen ritel memiliki karakteristik adanya barang dan jasa secara bersamaan. Terdapat perbedaan antara pengalaman yang dirasakan dalam lingkungan ritel dan non ritel terkait dengan cara pelanggan bernegosiasi di dalam toko, menemukan produk yang diinginkan, berinteraksi dengan karyawan toko, mengembalikan barang belanjaan dan hal-hal lainnya yang mempengaruhi persepsi pelanggan terhadap kualitas layanan. Keunikan jasa ritel tersebut menyebabkan perlunya perhatian khusus dalam memilih dan menggunakan skala pengukuran kualitas layanan (Kumar et al, 2018), sehingga penerapan ServQual pada lingkungan ritel telah diingatkan oleh Finn dan Lamb (1991), serta contoh penerapan ServQual pada lingkungan ritel dapat ditemukan pada kajian literatur yang dilakukan oleh Gaur dan Agrawal (2006).

Carman (1990) adalah peneliti yang pertama kali mencoba untuk menerapkan ServQual toko ritel yang menjual ban (industri ritel, menawarkan kombinasi barang dan jasa). Penelitian berhasil mengidentifikasi sembilan dimensi kualitas layanan menggunakan axis factor analysis diikuti dengan rotasi oblique. Hasil temuannya menyimpulkan bahwa ServQual tidak bersifat generik dan menyarankan instrumen diadaptasi dengan menambahkan dimensi atau atribut baru yang berkaitan dengan situasi yang ada. Finn dan Lamb (1991) menguji ServQual terhadap beberapa tipe toko ritel (departement store dan toko diskon). Confirmatory factor analysis tidak bisa menghasilkan model yang fit terhadap model ServQual yang diajukan untuk kedua format toko tersebut sehingga disimpulkan bahwa model ServQual tidak valid digunakan sebagai alat ukut kualitas layanan toko ritel tanpa adanya modifikasi, meskipun penelitian tersebut juga tidak dapat menyediakan model pengukuran yang dapat diterima.

Guiry et al (1992) memodifikasi 22 atribut ServQual menjadi 51 indikator dengan menghapus tujuh indikator dan menambahkan 36 indikator baru yang dirancang untuk mengkuru pelayanan pada toko ritel. Exploratory factor analysis menghasilkan tujuh dimensi di antaranya pelayanan personal selama berinteraksi 
dengan karyawan, keragaman produk, kehandalan prosedur transaksi, kemampuan karyawan sebelum terjadinya interaksi, bukti fisik, kebijakan pelayanan toko, dan harga. Gagliano dan Hatchote (1994) mengekstraksi empat dimensi yaitu perhatian personal, bukti fisik, kehandalan, dan kenyamanan saat meneliti sektor ritel pakaian. Dua dimensi yaitu perhatian personal dan kenyamanan tidak terkait dengan ServQUal, kelima dimensi ServQual tidak teridentifikasi dalam penelitian ini sehingga disimpulkan ServQual bukan alat ukur yang efektif untuk mengukur kualitas layanan pada toko apparel atau pakaian. Tabel 3 berikut memberikan ringkasan mengenai penelitian menggunakan model ServQual untuk usaha ritel.

\section{Tabel 3. Ringkasan Penelitian Menggunakan ServQual untuk Bisnis Ritel}

\begin{tabular}{lcl}
\hline \multicolumn{1}{c}{ Penulis } & Setting & \multicolumn{1}{c}{ Hasil } \\
\hline Carman (1990) & Ritel ban & $\begin{array}{l}\text { Sembilan factor kualitas layanan teridentifkasi } \\
\text { menggunakan axis factor analysis }\end{array}$ \\
$\begin{array}{l}\text { Finn dan Lamb } \\
\text { (1991) }\end{array}$ & $\begin{array}{c}\text { Department } \\
\text { Store dan Toko } \\
\text { diskon }\end{array}$ & $\begin{array}{l}\text { Confirmatory factor analysis tidak menunjukkan } \\
\text { department store maupun toko diskon }\end{array}$ \\
Guiry et al (1992) & Toko ritel & $\begin{array}{l}\text { 22 indikator ServQUal dimodifikasi menjadi 51 } \\
\text { indikator instrumen dengan menghilangkan 7 indikator } \\
\text { dan menambahkan 36 indikator baru. Exploratory } \\
\text { factor analysis menghasilkan tujuh dimensi }\end{array}$ \\
Gagliano dan & Toko apparel \\
Hatchote (1994) & $\begin{array}{l}\text { Menghasilkan 4 faktor yang mana dua di antaranya } \\
\text { tidak terkait dengan ServQual }\end{array}$ \\
\hline
\end{tabular}

Dunia usaha ritel mengalami perkembangan yang sangat pesat yang ditandai dengan semakin tingginya tuntutan pelanggan terhadap pelayanan ritel dan kualitas produk yangdijual (Yuen dan Chan, 2010), oleh karena itu sangat penting bagi perusahaan ritel untuk meningkatkan kualitas dan pelayanannya sehingga pada akhirnya dapat menciptakan loyalitas pelanggan (Bowen dan Chen McCain, 2015). Memelihara kualitas layanan dalam sebuah toko bukanlah pekerjaan mudah. Dibutuhkan pengukuran yang berkelanjutan untuk mengawasi dan mengidentifikasi area yang bertanggung jawab atas kualitas layanan. Kualitas layanan ritel juga dikaitkan dengan konsumsi pada masa yang akan datang dalam 
kaitannya dengan niat berkunjung kembali, pembelian, dan merekomendasikan toko kepada keluarga dan teman (Banerji dan Farooqi, 2013). Kualitas layanan dalam sektor ritel pada dasarnya berbeda dengan lingkungan jasa lainnya (Finn dan Lamb, 1991; Hanjunath dan Naven, 2012; Ushanta et al, 2014; dan Kaul, 2007). Pengembangan dan pengukuran kualitas dalam sektor ritel tidak dilakukan dengan menggunakan perspektif yang sama dengan sektor jasa umumnya. Dalam layanan ritel, sangat diperlukan untuk melihat kualitas dari perspektif jasa karena adanya barang dalam kegiatannya (Mehta et al, 2000). Baker et al (2002) mengemukakan dalam suatu toko ritel pengukuran kualitas layanan seharusnya mengikutsertakan kualitas produk yang disediakan (ini tidak terdapat dalam model ServQual) dan faktor-faktor lainnya yang terkait dengan penyampaian barang. Atas dasar pertimbangan tersebut Dabholkar et al pada tahun 1996 mengembangkan dan memvalidasi secara empiris Retail Service Quality Scale (RSQS) atau kualitas layanan ritel dan menghasilkan dimensi-dimensi yang penting bagi pelanggan ritel berdasarkan pada penelitian kualitatif (Kumar dan Sikdar, 2014).

Dalam penelitiannya, Dabholkar et al (1996) mengembangkan model hirearki struktur dan menghasilkan lima dimensi inti kualitas layanan ritel yang mana setiap dimensi berbeda satu dengan lainnya, terdiri atas physical aspect/aspek fisik, yaitu tampilan dan kenyamanan toko ritel. Dimensi ini memiliki kesamaan dengan aspek tangible ServQual namun memiliki makna yang lebih luas. Dimensi berikutnya adalah reliability/kehandalan yaitu kemampuan pengelola toko ritel untuk menepati janji dan melakukan pekerjaan secara benar. Dimensi ini memiliki kesamaan dengan aspek kehandalan versi ServQual. Dimensi ketiga adalah personnel interaction/interaksi karyawan, yaitu kemampuan karyawan untuk membantu dan menciptakan kepercayaan pada pelanggan. Aspek ini merupakan penggabungan antara dimensi daya tanggap dan jaminan versi ServQual. Dimensi keempat adalah problem solving/pemecahan masalah, yaitu kemampuan dan kemauan toko ritel untuk menerima pengembalian barang dan penanganan keluhan pelanggan. Dimensi merupakan suatu dimensi baru yang sama sekali tidak terdapat dalam model ServQual. Dimensi kelima 
adalah policy/kebijakan, yaitu berkaitan dengan jam operasional, kualitas produk, ketersediaan parkir, dan kartu kredit. Model kualitas layanan ritel ini terdiri atas lima dimensi yang dijelaskan dalam total 28 indikator, di mana 17 indikator merupakan adaptasi dari skala pengukuran model ServQual dan 11 indikator lainnya dikembangkan melalui kajian pustaka dan penelitian kualitatif. Tabel 4 berikut akan memberikan informasi mengenai dimensi dan skala kualitas layanan ritel.

Kualitas layanan ritel telah diuji oleh Dabholkar et al (1996) terhadap pelanggan department store di Amerika Serikat dan hasilnya menunjukkan bahwa skala kualitas layanan ritel memiliki validitas dan reliabilitas yang kuat. Hasil analisis data menunjukkan bahwa model yang diajukan sesuai dengan struktur faktor yang diajukan sebelumnya. Untuk memperkuat validitas maka diadakan penelitian kedua kalinya terhadap dua unit departemen store yang sama dengan penelitian pertama, dan hasilnya sekali menunjukkan model tersebut adalah fit. Dabholkar et al (1996) menyimpulkan bahwa model kualitas layanan ritel dapat digunakan pada usaha ritel yang menyediakan barang dan jasa seperti departemen store atau toko spesialisasi. Kualitas layanan ritel juga dapat digunakan sebagai alat untuk mengetahu area kualitas layanan yang lemah dan perlu ditingkatkan. Contoh studi menggunakan kualitas layanan ritel dapat dilihat pada tabel 5. Ahli pemasaran mengemukakan konsep kualitas layanan ritel adalah alat yang tepat untuk mengukur kualitas layanan suatu supermarket (Finn dan Lamb, 1991; Mehta et al, 2000; Sin dan Cheng, 2002; Thenmozhi dan Dhapanal, 2011)

Karena sifat jasa adalah tidak berbentuk fisik, pengukuruan terhadap kualtas layanan menjadi semakin menantang sehingga skala pengukuran yang dikembangkan untuk suatu jasa tidak dapat digunakan untuk untuk kategori jasa lainnya dan akan menjadi semakin rumit ketika suatu model dikembangkan di suatu negara dengan suatu budaya tertentu digunakan di negara lain dengan budaya yang berbeda (Kumar et al 2018). Seluruh indikator yang ada dalam skala kualitas layanan ritel pun tidak sepenuhnya dapat diterapkan terutama indikator ke 28 yaitu toko memiliki kartu kreditnya sendiri. Ini disebabkan karena tidak semua toko ritel bisa memiliki kartu kredit atau debit yang bersifat co-branding karena 
berbagai persyaratan yang tentunya tidak mudah dipenuhi oleh setiap toko ritel. Meskipun pada awalnya dikembangkan di Amerika Serikat, namun berbagai penelitian seperti tertera dalam Tabel 5 menunjukkan bahwa model kualitas layanan ritel dapat diterapkan di berbagai negara lain di antaranya Singapura, Afrika Selatan, Vietnam, India, Indonesia (Kota Mataram), dan Sri Lanka.

\section{Tabel 5. Ringkasan Studi Menggunakan Kualitas Layanan Ritel}

\begin{tabular}{|c|c|c|c|c|}
\hline Penulis & Setting penelitian & Sampel & Instrumen & Hasil temuan \\
\hline $\begin{array}{l}\text { Dabholkar et } \\
\text { al (1996) }\end{array}$ & $\begin{array}{c}\text { Amerika Serikat } \\
\text { bagian selatan }\end{array}$ & $\begin{array}{l}227 \text { responden dari tujuh } \\
\text { cabang atas dua } \\
\text { departemen store }\end{array}$ & $\begin{array}{l}\text { Kualitas layanan } \\
\text { ritel }\end{array}$ & $\begin{array}{l}\text { Struktur hirarki untuk kualitas layanan ritel diajukan termasuk lima } \\
\text { dimensi dasar meliputi aspek fisik, kehandalan interaksi karyawan, } \\
\text { pemecahan masalah, dan kebijakan. Tiga dari lima dimensi } \\
\text { memiliki masing-masing dua sub dimensi }\end{array}$ \\
\hline $\begin{array}{l}\text { Christo dan } \\
\text { Terblanche } \\
\text { (1997) }\end{array}$ & Afrika Selatan & pelanggan hypermarket & $\begin{array}{l}\text { Kualitas layanan } \\
\text { ritel }\end{array}$ & $\begin{array}{l}\text { Temuan menunjukkan bahwa model kualitas layanan yang } \\
\text { diajukan oleh Dabholkar et al adalah fit }\end{array}$ \\
\hline $\begin{array}{l}\text { Boshoff dan } \\
\text { Terblanche } \\
\text { (1997) }\end{array}$ & Afrika Selatan & & $\begin{array}{l}\text { Kualitas layanan } \\
\text { ritel }\end{array}$ & $\begin{array}{l}\text { Hasil menunjukkan bahwa modelkualitas layanan ritel dapat } \\
\text { diaplikasikan untuk separtment store, speciality store, dan } \\
\text { hypermarket di Afrika Selatan }\end{array}$ \\
\hline $\begin{array}{l}\text { Mehta et al } \\
(2000)\end{array}$ & Singapura & $\begin{array}{l}\text { Pelanggan supermarket } \\
\text { dan toko barang elektronik }\end{array}$ & $\begin{array}{l}\text { Kualitas layanan } \\
\text { ritel dan ServPerf }\end{array}$ & $\begin{array}{l}\text { Kualitas layanan ritel dapat diterapkan di supermarket. ServPerf } \\
\text { sangat baik diterapkan di lingkungan ritel. Lima dimensi baru } \\
\text { dihasilkan dari kombinasi kualitas layanan ritel dan ServPerf }\end{array}$ \\
\hline $\begin{array}{l}\text { Nguyen } \\
(2006)\end{array}$ & Vietnam & $\begin{array}{l}318 \text { supermarket di Ho Chi } \\
\text { Min City }\end{array}$ & $\begin{array}{l}\text { Kualitas layanan } \\
\text { dan penelitian } \\
\text { kualitatif }\end{array}$ & $\begin{array}{l}\text { Hasil menunjukkan bahwa lima dimensi kualitas layanan ritel } \\
\text { terdiri atas kualitas barang dagangan, layanan karyawan, tata } \\
\text { letak toko ritel, tampilan, dan keamanan }\end{array}$ \\
\hline $\begin{array}{l}\text { Subhasini } \\
\text { Kaul (2007) }\end{array}$ & India & $\begin{array}{l}144 \text { pembeli dewasa di } \\
\text { toko apparel di Kota } \\
\text { Bangalore }\end{array}$ & $\begin{array}{l}\text { Kualitas layanan } \\
\text { ritel }\end{array}$ & $\begin{array}{l}\text { Hasil menunjukkan lima dimensi kualitas layanan ritel tidak } \\
\text { teridentifikasi secara jelas. Dimensi aspek fisik merupakan satu- } \\
\text { satunya dimensi yang relatif jelas. Kualitas layanan ritel tidak } \\
\text { dapat diterapkan di India }\end{array}$ \\
\hline $\begin{array}{l}\text { Nguyen } \\
(2007)\end{array}$ & Vietnam & $\begin{array}{l}440 \text { pelanggan di berbagai } \\
\text { supermarket di Kota Ho } \\
\text { Chi Min }\end{array}$ & $\begin{array}{l}\text { Kualitas layanan } \\
\text { ritel }\end{array}$ & $\begin{array}{l}\text { Hasil menunjukkan terdapat kualitas layanan ritel terdiri atas } \\
\text { empat faktor yaitu pelayanan karyawan, aspek fisik, kebijakan, } \\
\text { dan keamanan }\end{array}$ \\
\hline $\begin{array}{l}\text { Anupam Das } \\
\text { et al (2008) }\end{array}$ & Kazakhtan & $\begin{array}{l}220 \text { responden di Kota } \\
\text { Amaty, Kazakhtan }\end{array}$ & $\begin{array}{l}\text { Kualitas layanan } \\
\text { ritel }\end{array}$ & Temuan mengindikasikan dimensi kualitas layanan adalah fit \\
\hline $\begin{array}{l}\text { Benni } \\
\text { Kusyana } \\
(2012)\end{array}$ & Kota Mataram & $\begin{array}{l}195 \text { responden yang } \\
\text { merupakan pelanggan } \\
\text { supermarket utama di } \\
\text { Kota Mataram }\end{array}$ & $\begin{array}{l}\text { Kualitas layanan } \\
\text { ritel, kepuasan, } \\
\text { nilai pelanggan, } \\
\text { dan word of } \\
\text { mouth } \\
\text { communication }\end{array}$ & $\begin{array}{l}\text { Hasil uji analisis faktor konfirmatori menunjukkan bahwa model } \\
\text { pengukuran masuk kategori fit, baik untuk orde pertama dan orde } \\
\text { kedua, serta model kualitas layanan ritel mampu menjadi } \\
\text { penyebab timbulnya nilai pelanggan, kepuasan, dan word of } \\
\text { mouth communication. }\end{array}$ \\
\hline $\begin{array}{l}\text { Ushantha et } \\
\text { al (2014) }\end{array}$ & Sri Lanka & $\begin{array}{l}168 \text { pelanggan toko ritel } \\
\text { besar di Distrik Kolombo }\end{array}$ & $\begin{array}{l}\text { Kualitas layanan } \\
\text { ritel dan } \\
\text { kepuasan } \\
\text { pelanggan }\end{array}$ & $\begin{array}{l}\text { Lima Dimensi kualitas layanan ritel termasuk kategori fit dan } \\
\text { terbukti model tersebut mampu untuk mempengaruhi kepuasan } \\
\text { pelanggan }\end{array}$ \\
\hline
\end{tabular}

\section{Skala Pengukuran Kualitas Layanan Lainnya.}

Seiring berjalannya waktu, kualitas layanan telah diaplikasikan untuk banyak kategori industri jasa yang menunjukkan bahwa kualitas layanan sangat stabil dan diterima di berbagai kategori industri (Ladhari, 2009). Penelitian demi penelitian dilakukan untuk mengembangkan model kualitas layanan yang lebih spesifik agar dapat disesuaikan dengan suatu jenis jasa.

Berdasarkan model ServQual, Knutson et al (1990) mengembangkan model LODGESERV dengan total 26 indikator yang diapliaksikan pada perusahaan penginapan, sedangkan untuk industri restoran dikembangkan model DINESERV oleh Stevens et al (1995) yang juga berbasis pada model ServQual 
namun hanya menitikberatkan pada kinerja aktual pelayanan yang lebih dikenal sebagai konsep ServPerf. Dalam kontek layanan elektronik atau dikenal dengan istilah electronic service quality (e-servqual), salah satu skala pengukuran eservqual yang paling banyak digunakan adalah model yang dikemukakan oleh Parasuraman et al pada tahun 2005 yang terdiri atas E-S-Qual yang mencakup efisiensi, pemenuhan, ketersediaan system, dan privasi, serta E-RecS-Qual yang mencakup ketanggapan, kompensasi, dan kontak.

\section{SIMPULAN DAN IMPLIKASI MANAJERIAL}

\section{Simpulan}

Kajian literatur ini menjelaskan berbagai macam skala pengukuran yang digunakan dalam mengukur kualitas layanan yang dikembangkan sebelum tahun 2000 yaitu ServQual, ServPerf, dan Retail Service Quality Scale (RSQS). Meskipun banyak kritik terhadap model ServQual yang dikemukakan oleh Parasuraman et al (1988) namun kenyataannya bahwa model tersebut telah menjadi dasar bagi pengembangan skala-skala pengukuran kualitas layanan lainnya. ServQual diyakini hingga kini lebih tepat untuk digunakan dalam konteks skala pengukuran kualitas layanan perusahaan jasa murni, dalam artian tidak disertai dengan barang seperti bank. Berikutnya adalah skala pengukuran ServPerf yang pada dasarnya memiliki kesamaan dengan dimensi dan atribut dengan ServQual namun perbedaannya yaitu ServPerf memandang kepuasan sebagai suatu sikap sehingga ServPerf hanya mengukur penilaian pelanggan atas kinerja kualitas layanan.

Meskipun terdapat pandangan yang berbeda dalam merumuskan dimensi dan atribut skala pengukuran kualitas layanan, namun pengukuran terhadap kualitas layanan merupakan alat yang sangat penting bagi manajemen untuk memahami kebutuhan dan keinginan pelanggan dengan menganalisis pengalaman yang dirasakan pelanggan terhadap layanan yang telah diberikan. Pengukuran kualitas layanan mampu membantu perusahaan dalam menemukan kelemahan dan keunggulan untuk kemudian merumuskan pelayanan yang lebih baik kepada pelanggan. Semakin baik kualitas layanan yang diberikan maka kepuasan dan loyalitas pelanggan yang tercipta akan semakin baik sehingga pada akhirnya 
memunculkan berbagai macam skala pengukuran kualitas layanan yang semakin spesifik.

Kebutuhan akan adanya skala pengukuran kualitas layanan yang lebih spesifik kini semakin meningkat karena skala pengukuran generik yaitu ServQual tidak lagi dianggap mampu memenuhi kebutuhan semua jenis usaha jasa. Pengembangan skala pengukuran kualitas layanan sejak tahun 1984 hingga saat ini telah mengalami perkembangan yang sangat pesat seiring dengan terjadi fenomena pelayanan berbasis teknologi informasi atau yang dikenal dengan nama electronic commerce (e-commerce). Ke depannya, skala pengukuran kualitas layanan akan sangat bergantung pada jenis usaha jasa, situasi, waktu, kebutuhan, dan berbagai faktor lainnya.

\section{Implikasi Manajerial}

Kajian literatur ini diharapkan dapat menjadi masukan baik bagi para peneliti, manajer, dan praktisi sebagai berikut :

1. Perlu dikembangkannya model-model kualitas layanan lainnya yang lebih spesifik agar sesuai dengan jenis usaha.

2. Perusahaan yang sukses dalam menciptakan pelayanan yang berkualitas harus tetap melakukan peningkatan kualitas layanan dengan terus melakukan survey terhadap kepuasan pelanggan dan benchmarking.

3. Penanganan keluhan melalui manajemen komplain sangat dibutuhkan untuk mengetahui ketidakpuasan pelanggan atas layanan yang diberikan.

4. Pelanggan harus menjadi fokus bagi setiap perusahaan karena pelanggan yang akan memberikan penilaian pada kinerja pelayanan perusahaan.

5. Mengetahui harapan pelanggan adalah salah satu cara yang sangat efektif untuk bisa merancang kualitas layanan agar dapat memberikan keunggulan kompetitif bagi perusahaan.

6. Lakukan survey secara berkala untuk mengetahui penilaian pelanggan terhadap kualitas layanan.

7. Peningkatan kualitas layanan dalam perusahaan harus menjadi tanggung jawab bagi seluruh komponen perusahaan. 


\section{DAFTAR PUSTAKA}

Abu-El Samen, A. A., Akroush, M. N., \& Abu-Lail, B. N. 2013. Mobile SERVQUAL: a comparative analysis of customers' and managers' perceptions. International Journal of Quality \& Reliability Management, 30, 403-425.

Ali, F., Y. Zhou., Hussain, K., Kumat, P., Neethiahnanthan, N., dan. Ravagan, A. 2016. Quality assurance in education. Quality Assurance in Education, 24(1), 7-94.

Das, A., Saha, G.C., dan Banik, N.L. 2008. Retail service quality scale: examining applicability in a transition economy. POMS 19TH Conference.

Baker, J., Parasuraman, A., Grewal, D., dan Voss, G. B. 2002. The influence of multiple store environment cues on perceived merchandise value and patronage intentions. The Journal of Marketing. Vol. 66, No. 2, pp. 120141

Banahene, S., Ahudey, E., \& Asamoah, A. 2017. Analysis of servqual application to service quality measurement and its impact on loyalty in ghanaian private universities. Journal of Management and Strategy, 8 (4), 8 - 33.

Banerji, R., dan Farooqi, R. 2013. Evaluation of retail service quality by using rsqs model : a case study on big bazaar hypermarkets in Nct of Delhi (India).

Kusyana, D. N. B. 2012. Pengaruh Kualitas Layanan Ritel Terhadap Nilai Pelanggan, Kepuasan, dan Word of Mouth Communication pelanggan Supermarket Modern di Kota Mataram. Universitas Mataram.

Boshoff, C., dan Terblanche, N. S. 1997. Measuring retail service quality: a replication study, South African Journal of Business Management, 1997 No. 4.

Bowen, J.T., dan Chen, S. L. 2001. The relationship between customer loyalty and customer satisafction. International Journal of Contemporary Hospitality Management, Vol. 13, No. 5, pp. 213-217

Bowen, J. T., \& Chen McCain, S.L. 2015. Transitioning loyalty programs : a commentary on the relationship between customer loyalty and customer satisfaction. International Journal of Contemporary Hospitality Management, 27(3), 415-430

Brady, M. K., dan Cronin, J.J. 2001. Some new thoughts on conceptualizing perceived service quality: A hierarchical approach. Journal of Marketing, 65(3), 34-49.

Carman, J.M. 1990, Consumer perceptions of service quality: an assessment of the servqual dimensions, Journal of Retailing, 1990, pp. 33-55.

Caruana, A. 2000. Service Loyalty : The effects of service quality and the mediating role of customer satisfaction. European Journal of Marketing, Vol. 36, No. 7/8, pp. 811-828

Christo, B. dan Terblanche, N.S. 1997. Measuring retail service quality: a replication study. South African Journal of Business Management, Vol. 28, Issue $4,123-128$. 
Cronin, J. J., \&. Taylor, S. A. 1992. Measuring service quality - a reexamination and extension. Journal of Marketing, 56(3), 55-68.

Cronin, J. J., dan Taylor, S. A. 1994. Servperf versus servqual - reconciling performanc-based and perceptions-minus-expectations measurement of service quality. Journal of Marketing, 58(1), 125-131

Dalholkar, P.A.,.Thorpe, D.I., dan.Rentz, J.O. 1996. A measure of service quality for retail stores: scale development and validation. Journal of Academy of Marketing Science, Winter, 24, 1

Finn, D. W. dan Charles, W.L. 1991. An evaluation of the servqual scale in a retailing setting. Advances in Consumer Research, Vol. 18, pp. 483-490

Fotaki, M. 2015. Why and how is compassion neccesary to provide good quality healthcare?. International journal Health Policy Management, 4(4), 199201

Gagliano, K.B. and Hathcote, J. 1994. Customer expectations and perceptions of service quality in apparel retailing. Journal of Services Marketing, 1994, No.1, pp. 60-9.

Gaur, S.S., \& Agrawal, R. 2006. Service quality measurement in retail store context: a review of advances made using servqual and rsqs. The Marketing Review, 243-256.

Ghotbabadi, A.R., Feiz, S., dan. Baharun, R. 2015. Service quality measurement : a review. International Journal of Acedemic Research in Business and Social Sciences, Vol. 5, No. 2

Guiry, M. H. W., dan Weitz, B. A. 1992, Consumers' evaluation of retail store service quality and its influence on store choice. Working paper University of Florida.

Hanjunath, A. K. G., dan Naveen, K. H. 2012.A study of ritel service quality in organized riteling. International Journal of Engineering and Management Science, Vol. 3, No. 3, pp. 370-372

Harwood, T., dan. Garry, T 2008. Relationship marketing : Perspective, Dimensions and Contexts. Edisi Pertama. Maidenhead : McGraw-Hill Education

Kabadayi, N., dan Cirpin, B. G. 2016. Service quality analysis using a fuzzy ahp methodology : a case study in veterinary hospital in turkey. International Conference on Industrial Engineering and Operations Management. USA, September 23-23.

Kaul, S. 2007. Measuring retail service quality: examining applicability of international research perspectives in india. Vikalpa: The Journal for Decision Makers 32.1

Khatibi, A.A., Ismail, H., dan Thyagarajan, V. 2002. What drives customer loyalty : an analysis from the telecommunications industry. Journal of Targeting, Measurement and Analysis for Marketing, Vol. 11, No. 1, pp. 34-44.

Knutson, B., Stevens, P., Wullaert, C., Patton, M. dan Yokoyama, F. 1990. Lodgserv : a service quality index for the lodging industry. Hospitality Research Journal, 14(2), 277- 284. 
Kumar, A., dan. Sikdar, P. 2014. Retail service quality assessment-a scale validation study in indian perspective. AIMA Journal of Management and Research, Vol. 8, Issue1/4.

Kumar, A., Chaudhuri, S., dan Biswal, B.K. 2018. Service quality scales - a review. International Journal of Mechanic Engineering and Technology, Vol. 9, Issue 3, pp. 497-505

Ladhari, R. 2009. Service quality, emotional satisfaction, and behavioural intentions : a study in the hotel industry. Managing Service Quality, 19 (3), 308-331.

Marshall, G., dan Murdoch, I. 2001. Service quality in consulting marketing engineers. International Journal of Constr Mark. 3(1):41-9

Mehta, S. C., Lalwani, A. K., dan Li Han, S. 2000. Service quality in retailing: relative efficiency of alternative measurement scales for different productservice environments. International Journal of Retail \& Distribution Management, 28(2), 62-72.

Nguyen, T.M.T. 2006. Service quality, satisfaction and loyalty of customer supermarket in Hochiminh. Science \& Technology Development, Vol.10

Nguyen T.M.T. 2007. Market research, VNU Publisher, Hochiminh

Ojo, T.K., Mireku, D.O., Dauda, S., dan Nutsogbodo, R.Y. 2014. Service quality and customer satisfaction of public transport on Cape Coast-Accra Route, Ghana. Developing Country Studies, 4(18).

Parasuraman, A., Zeithaml, V.A., dan Berry, L.L. 1985. A conceptual model of service quality and its implication for future research. Journal of Marketing, 49(4), 10.

Parasuraman, A.,. Zeithmal, V. A., dan Berry, L. L. 1988. Servqual : a multiple item for measuring consumer perception of service quality. Journal of Retailing, Vol. 6, No. 1

Parasuraman, A.,. Zeithmal, V. A., dan A. Malhotra. 2005. E-S-Qual : A multiple item scale for accessing electronic service quality. Journal of Service Research, 7, 213 - 233.

Peprah, A.A., dan Atarah, B.A. 2014. Assesing patient's satisfaction using servqual model : a case of Sunyani Regional Hospital, Ghana

Prakash, A., dan Mohanty, R. P. 2012. Understanding service quality. Production Planning and Control, 1-16.

Seth, N., Deshmukh, S. G., dan Vrat, P. 2005. Service quality models: a review. International Journal of Quality \& Reliability Management, 22(9), 913949.

Shahin, A., dan. Samea, M. 2010. Developing the models of service quality gaps: a critical discussion. Business Management and Strategy, 1(1), 1-11.

Sin, N., dan Cheung, J. 2002. A measure of retail service quality. Marketing Intelligence and Planning.

Siu, N.Y.M., dan Cheung, J.T. 2001. A measure of retail service quality. Marketing Intelligence and Planning, Vol. 19, No. 2, pp. 88-96.

Sureshchandar, G.S., Rajendran, C., dan Kamalanabhan, T.J. 2001. Customer perceptions of service quality : a critique. Total Quality Management, 12 (1), 111-124. 
Thenmozhi, S., dan Dhanapal, D. 2011. Unorganised retailing in India-a study on retail service quality. European journal of social sciences, 23(1), 71-78.

Ushantha, R. A. C.,. Wijeratne, A. W., dan Chchunthan, S. 2014. An assessment of ritel service quality : an empirical study of the rsqs in Sri Lankan supermarkets. Developing Country Studies, Vol. 4, No. 3.

Yuen, E. F., dan Chan, S. S. 2010. The effect of retail service quality and product quality on customer loyalty. Journal of Database Marketing \& Customer Strategy Management, 17(3-4), 222-240.

Yusof, N., Rahman, F., Jamil, M., dan Iranmanesh, M. 2014. Measuring the quality of ecotourism services: case study based model validation. SAGE Open 